\title{
Auditing and Weak Bonding Function in Relation to the Agents of Zaibatsu (Large, Family-Owned Industrial Conglomerates) in Japan during 1930s
}

\author{
Ichirou Shiobara \\ Waseda University, Tokyo, Japan \\ Email: ishiobara@yahoo.com
}

Received 1 April 2014; revised 30 April 2014; accepted 10 May 2014

Copyright (C) 2014 by author and Scientific Research Publishing Inc. This work is licensed under the Creative Commons Attribution International License (CC BY). http://creativecommons.org/licenses/by/4.0/

(c) () Op Open Access

\section{Abstract}

This paper has been inspired by the paper issued by Evans, and the title of which is "Auditing and Audit Firms in Germany before 1931" in 2003 on Accounting Historians Journal [1]. Although some academics in the field of international accounting refer to accounting events during 1930s in some specific nations in the world as the main subject in their research, it seems to be rare to make allusion to events surrounding external statutory audit by professionals (ESAP, hereafter) in the world during 1930s, the decade characterized as the inter-war period, collectively. Under such a situation Evans Lisa tried to shed light on the comparatively slow development of the statutory audit in Germany, examine the different attitudes to the legal and organizational forms of audit firms, and to analyze the development of German auditing and audit firms prior to their statutory regulation in 1931. Evans' work, however, has the other aspect of developing the critique of agency theory assumptions in historical contexts. In this aspect, this paper shall rely on the agency theory as the framework of searching the reasons of Japan's specialty in relation to introducing the external statutory audit by professionals during the decade when EVANS referred to, especially focusing on the monitoring and bonding mechanism of ZAIBATSU. In literature, many papers on agency theories focus on monitoring and the way of incentives by principals. In this respect, the development of German ESAP justifies EVANS' approach. On the contrary, in reaching the profound reasons that underlie the behaviors of related parties in relation to introducing ESAP, it's important to pay attention to the conducts of managements that are agents, especially their bonding manner. According to Jensen and Mecling, there is no difference that actually makes the monitoring expenditures and also it will pay the owner-manager to engage in bonding activities and to write contracts which allow monitoring as long as the marginal benefits of each are greater than their marginal cost. If so, generally we can say that the balance of monitoring and bonding might be beneficial to both principals and agents. And also we can expect the situation in which too 
strong monitoring by the principals might lesson the bonding efforts by the agents. In this paper, I would like to deepen the understanding of the roles and places of managements of ZAIBATSU during 1930s in addition to the situation of Japanese modern big companies, especially those of which occupied the status of followers of ZAIBATSU.

\section{Keywords}

\section{Zaibatsu, Governance, Agency Theory, Principal, Agent, Internal Control, Internal Auditing, External Statutory Audit by Professionals, Monitoring, Bonding}

\section{Introduction}

I've written some essays on 1930s regime of External Statutory Audit by Professionals (ESAP) in relation to JAPAN.

Especially in the paper in English titled "External Auditing in Japan-Its participation in 1930s regime of US based External Auditing" [2] in which I insisted that "although some academics in the field of international accounting refer to accounting events during 1930s in some specific nations in the world as the main subject in their research, it seems to be rare to make allusion to events surrounding external statutory audit by professionals (ESAP, hereafter) in the world during 1930s, the decade characterized as the inter-war period, collectively".

Under such a situation Evans tried to shed light on the comparatively slow development of the statutory audit in Germany, examine the different attitudes to the legal and organizational forms of audit firms, and to analyze the development of German auditing and audit firms prior to their statutory regulation in 1931.

In the above mentioned article, we focused our attention to the decade of the 1930's not only from the perspective of specific nations but also from that of collections of nations as the representatives of the world in which I referred to 5 countries. I would like to, however, delete France in this paper because of my intention to avoid unnecessary arguments.

Moreover we tried to base our arguments on the historical facts and observational propositions on facts as far as possible, so as to create the useful tool to explain anomalous phenomena surrounding ESAP in Japan that is no entry to American based 1930s regime by giving our interpretations to these facts [1].

Also, this paper shall rely on the agency theory as the framework of searching the reasons of Japan's specialty in relation to introducing the external statutory audit by professionals during the decade when EVANS referred to, especially focusing on the monitoring and bonding mechanism of Zaibatsu.

According to Jensen and Meckling [3], an agency relationship was defined "as a contract under which one or more persons (the principal (s)) engage another person (the agent) to perform some service on their behalf which involves delegating some decision making authority to the agent”. Of course in the case of Zaibatsu also, as shown below, there were some traits of possibility to look upon them as the nexus of contracts. So it might be allowed in the following sessions to argue the matters in the framework of agency theories [2].

\subsection{What's Zaibatsu?}

Before entering into the subject matter, some methodological affairs shall be pointed out. As Watts and Zimmerman [4] did, "the evidence analyzed in this paper is qualitative in nature and does not lend itself to hypothesis testing using large samples and econometric methods." In this paper also, we would like to follow them.

According to economic historians majoring in Zaibatsu, the concept of Zaibatsu is a little ambiguous. Here we shall be satisfied with citing the explanation given by Hiroshi Matsumoto [5] in his farewell lecture at YOKOHAMA UNIVERSITY titled "Zaibatsu in Japan" He shows us some of definition list. Some of them shall be shown below:

1) A group of parent companies invested by the family and its relatives, at the core of which those subsidiaries occupied by them are compelled to be engaged in the operation of some businesses and big ones of which led the some industries to the state of oligopoly.

2) Multilateral business entities which were under the control of closely related family and its relatives.

3) Multilateral business entities which were under the control of closely related family and its relatives which 
had the monopolistic states.

We intend to rely upon some of them according to necessity to develop our arguments. Putting aside definition problems, they can be classified into two groups. The ones are business entities grown up from businessmen with prerogative power including MITSUI and SUMITOMO. The others are the business entities grown up from businessmen with political contacts with the government at the ties of MEIJI RESTORATION, which include MITSUBISHI, YASUDA, HURUKAWA, OOKURA, FIJITA and others. Among both of them, as shown by the figure, MITSUI, MITSUBISHI, SUMITOMO and YASUDA are called Big Four according to their occupation of industrial markets (Table 1).

Among them we would like to focus our attention in the following section to MITSUBISHI Zaibatsu.

\subsection{Development of Mitsubishi during 1930s and Years before Them}

Zaibatsu existed during 78 years from 1867 to 1945 . We intend to describe the matters during 1930s. We would like to treat MITSUBISHI Zaibatsu, however, from its embryo stage to 1930s as the introductory part of the main section.

The founder of Mitsubishi zaibatsu, that is, IWAZAKI family, established MITSUBISHISHA to control several businesses under their holdings. By this control system each business had to ask for MITSUBISHA's order about the business which needed the increase of fixed assets. On employment affairs also needed the permission of MITSUBISHISHA. The other parts of the businesses were delegated to the chief of the businesses.

According to one historian of ZAIBATSU this control system of MITSUBISHISHA were said to be possible by means of modern accounting system which MITSUBISHI introduced at the early stage of its development. After having introduced double entry book-keeping, its accounting system developed following enlargement and diversification of its businesses. MITSUBISHI used this system for controlling businesses under their holdings [6].

Later in place of MITSUBISHISHA, MITSUBISHI limited partnership company was established to get clear the legal status of holdings by IWAZAKI family. This company introduced the divisional system in 1908 to control businesses under its holding [6].

IWAZAKI K KOYATA who inherited from KYUYA presidency of MITSUBISHI limited partnership company performed some revolutionary changes of its system of control by introducing holding companies [7].

In 1917 one of divisions, "shipbuilding business" of MITSUBISHI limited partnership company became Mitsubishi Shipbuilding Co., Ltd. Then in 1918 Mitsubishi Mining Company Ltd., was established and assumed the assets of mining-related divisions [8], including the establishment of Mitsubishi Corporation absorbing business division and that of Mitsubishi Warehouse Co., Ltd. as the successor of Mitsubishi, Logistics Corporation [9], in 1919 Mitsubishi Bank, Ltd. after bank division and MITSUBISHI Marine and Fire Insurance Co., Ltd. after insurance division.

As shown above, these newly established companies were engaged in their own businesses which held a controlling block of shares in the affiliated companies concentrated on control of these affiliated companies after having exchanged contracts to transfer the right of doing businesses [5].

On the reasons why IWAZAKI KOYATA performed such revolutionary changes of its system of control by introducing holding companies, Masashi AOCHI argued the following three:

\begin{tabular}{ccccc}
\multicolumn{5}{c}{ Table 1. Constitution of investment in the area of industries by big four. } \\
\hline & MITSUI & MITSUBISHI & SUMITOMO & YASUDA \\
\hline finance & 11.5 & $\%$ & $\%$ & $\%$ \\
heavy industry & 48.7 & 22.1 & 15.1 & 35.2 \\
light industry & 138 & 45.7 & 44.1 & 8.3 \\
others & 26.0 & 11.5 & 9.4 & 32.9 \\
total & $100(61,259)$ & $100(57,400)$ & $100(38,684)$ & $100(25,502)$ \\
\hline
\end{tabular}

(Cited from Hiroshi Matsumoto, ibid). In the parenthesis, sums of investment are shown; monetary unit is ¥million. 
1) The Way to Reduce Taxes.

In 1913 tax law was reformed to levy corporation tax at the predefined rate of 25 - 1000 ths for limited partnership company and 62.5 - 1000 ths for stock holding companies. Furthermore to the MITSUBISHI limited partnership company was to be applied progressive tax. It should have been favorable to it to change its businesses to holding companies. The reason why MITSUBISHI limited partnership company itself did not take the form of stock holding company can be found in the reason.

2) Evading Risks and Planning the Diffusion of Its Businesses.

If it divides its businesses into several holding companies, it should have been favorable to it because limited partnership company could be stock holders of its holding companies, and also establish several holding companies but one contributes to diffusion of its businesses which help each holding company avoid bankruptcy at the same time compared to the risk which it should have encountered.

3) Intention to Fund Social Money from the Market.

By means of getting its businesses into holding companies, making their shares public could permit it fund social money. This was the way IWAZAKI K KOYATA himself supported in his special messages [3].

4) Intention to Efficiently Integrate Different Sorts of Businesses.

IWAZAKI K KOYATA himself made it clear in his speech that the rapid development of JAPAN caused businesses of his limited partnership company to have developed and to change the system by getting them to holding companies [7].

On the other hand IWAZAKI KOYATA did not change his limited partnership company to the form of stock holding company. Its reasons are argued by historians in the reversal ways given to way of introducing holding companies. These are:

a) Realization of merits of limited liability by becoming shareholders of its holding companies.

b) Avoidance of possibility of destroying the structure of holding and occupying by IWAZAKI Family if it employed the form of stock holding company by inflow of funds from outside parties [4] [5].

\section{Mitsubishi Zaibatsu and Monitoring System}

\subsection{Mitsubishi Zaibatsu and Professional Managements}

From the early stage of its development MITSUBISHI ZAIBATSU employed professional management among whom the most famous were KOUHEI KONDOU, HEIGOROU SOUDA and RYOUHEI TOYOKAWA. The most peculiar characteristics of these managements including persons shown above, needless to say about those of holding companies, are said to be that in substance they had huge authority but against ZAIBATSU FAMILY, they occupied the status of servants. All businesses of holding companies were considered to be the assets of FAMIIY [5].

We can find their names on the site.

According to TAKEDA [8], amongst the stock holders of holding companies held by MITSUBISHI limited partnership company, IWAZAKI FAMILY showed peculiar characteristics. Their investment in holding companies was limited to IWAZAKI FAMILY upon this understanding; we will proceed on the assumption that, as shown above, there were some traits of possibility to look upon them as the nexus of contracts. So it might be allowed in the following sessions to argue the matters in the framework of agency theories referring to Jensen and Meckling's arguments, especially focusing on the monitoring and bonding mechanism of Zaibatsu.

\subsection{Strict System of Monitoring of Zaibatsu}

As TAKEDA [8] explains, in the literature on the study of ZAIBATSU "strict system of monitoring” has been emphasized. AOCHI claims that MITSUBISHI limited partnership company was in the stage of strengthening its monitoring function [6].

In 1916 president of MITSUBISHI limited partnership company, KOYATA performed internal audit to all businesses and claimed the internal auditors to report the results to him. Before that time, in $1875 \mathrm{MEIJI}$ government gave 31 vessels to MITSUBISHI SHOUKAI (former organization of MITSUBISHI limited partnership company) for the condition of accounting report to the government and establishment of good accounting system. Since then, as shown above, it introduced modern accounting system which were based on double entry book-keeping and its accounting system developed following enlargement and diversification of its businesses. 
MITSUBISHI used this system for controlling businesses under their holdings. In the same year MITSUBISHI SHOUKAI changed its name to POSTAL STEAMBOAT MITSUBISHI COMPNY. And it prescribed the rules on its double entry bookkeeping in the framework of its rules on POSTAL STEAMBOAT MITSUBISHI COMPNY.

However AOCHI [7] proceeds to argue that in spite of such superior accounting system, its performance was extremely short handed.

In this occasion, president KOYATA claimed in 1917 compliance with the rules issued in his "Special Notes" sent to the officers of his businesses [7]. If so, severe monitoring system including internal auditing taken by MITSUBISHI started from irregularities which is different from auditing in USA vogue between 1900 and 1914 to certify B/S for use by bankers and is very similar to auditing in USA which had the attest function depended mainly on verification of bookkeeping detail.

Anyhow, immediately after having introduced the system of holding companies, MITSUBISHI limited partnership company set the department of supervision. In article 22 of its prescription of office organizations defined the roles of this department as to be engaged in accounting work of this company, works of accounting, operating audit, audit on investment affairs in relation to its holding companies. AOCHI considers this department as the sector to perform monitoring function [7].

By this way, MITSUBISHI limited partnership company succeeded in nourishing the soil to grow the managements of its holding companies to be engaged in their specialty of operating their own businesses by reducing their responsibility as the management of capital [7].

\subsection{Tendency of Emphasizing Monitoring amongst Literatures}

In general, arguments on auditing emphasize its role as the tool of monitoring. Watts and Zimmerman stated, "Auditing is one of the ways in which the contracts are monitored [4]".

Further, they said, "the papers that stress the importance of monitoring in the theory of the firm analyze the incentive (agency or control) problems that exist in different types of firms (partnerships, nonprofit firms, corporations, etc.).” W.Z. In this meaning, severe system of monitoring taken by MITSUBISHI ZAIBATSU paralleled to the general tenancy.

On the other hand, as shown above, according to Jensen and Mecling [3], "there is no difference who actually makes the monitoring expenditures and also it will pay the owner-manager to engage in bonding activities and to write contracts which allow monitoring as long as the marginal benefits of each are greater than their marginal cost".

If so, generally we can say that the balance of monitoring and bonding might be beneficial to both principals and agents. And also we can expect the situation in which too strong monitoring by the principals might lesson the bonding efforts by the agents.

\section{Concluding Remarks-Peculiarity of Severe System of Monitoring Taken by Mitsubishi Zaibatsu}

We emphasize that the whole affairs of Zaibatsu could be looked upon as inward oriented in contrast to the similar organizations during 1930s in other developed countries which could be looked upon as outward oriented.

Here we can show their traits in several episodes referring to the following matters taken by Mitsubishi Zaibatsu in its embryo stages.

For example, it established commercial school and merchant marine school under its own power to get the talents who can be grown up as the faithful employees.

In contrast to this peculiarity, general picture of monitoring system in the countries taken in the attached table can be found in the following statement by Watts and Zimmerman.

"The first joint stock companies were audited." W.Z.

"The accounts of the early joint stock companies were audited by a committee of shareholders (members) and/or directors." W.Z.

"This practice continued into the eighteenth and nineteenth centuries." W.Z.

"The auditing was voluntary.” W.Z.

"The hypothesis advanced here is that committees of auditors survived because they were an efficient method of monitoring contracts between managers and those supplying capital." W.Z. 
"The U.K. company acts from 1844 to 1900 did not require outside auditors.” W.Z.

Even in those countries, ESAP was not common. For example, Watts and Zimmerman, stated that "the use of outside professional auditors did not become common until the latter half of the nineteenth century in the United Kingdom and the early part of this century in the United States.” W.Z. However in those countries, monitoring system of joint stock companies progressed alongside the growth of outside professionals. In this meaning, this kind of monitoring system can be seen as an outward-looking one. In those countries, as shown in the attached tables, after voluntary auditing, ESAP was a common style.

On the contrary, the severe system of monitoring MITSUBISHI ZAIBATSU seems to have prevented the growth of ESAP. Accounting system, internal audit, internal control system and others were constructed from the strict monitoring aspect in the framework of MITSUBISHI Limited Liability Company. As Watts and Zimmerman emphasized, in the countries shown on the attachments, bonding has been used throughout the history of the business corporation except Japan. In this paper we developed our argument on the origin of such affairs caused by too much severe system taken in the framework of Zaibatsu dependent economy in Japan during 1930s.

\section{References}

[1] Evans, L. (2003) Auditing and Audit Firms in Germany before 1931. Accounting Historians Journal, 30, $29-65$.

[2] Shiobara, I. (2002) External Auditing in Japan-Its Participation in 1930s Regime of US Based External Auditing-Huitiemes Journeesd histoire de la comptabilite et du management, Les nouvelles technologies dansl' histoire 21-22, 111-133.

[3] Jensen, M.C. and Meckling, W.H. (1976) Theory of the Firm: Managerial Behavior, Agency Costs and Ownership Structure. Journal of Financial Economics, 3, 305-360.

[4] Watts, R.L. and Zimmerman, J.L. (1983) Agency Problems, Auditing, and the Theory of the Firm: Some Evidence. Journal of Law and Economics, 26, 613-633. http://www.jstor.org/stable/725039

[5] (2004) Hiroshi Matsumoto: Zaibatsu of Japan: History of Their Formation, Development and Dissolution. Economia, $55,1$.

[6] Tetsuji, O. (1999) History of Holding Companies. Chikuma Shinsho.

[7] Masashi, A. (Year) Corporate Governance of Mitsubishi Limited Liability Company, Kyoto University Economic Society. Kyoto University Economic Review, Change of MITSUBISHI Limited Liability Company during War II, 169. http://hdl.handle.net/10110/9447.2013,4,6

[8] Haruhito, T. (2013) Zaibatsu and Internal Capital Market. http://www.takeda.e.u-tokyo.ac.jp/gyoseki/naibushihon.pdf

[9] http://www.mmc.co.jp/corporate/en/corporate/history.html 


\section{Notes}

1) As shown on the table, in 1914 offering of "Bill on Professional Accountants" to the 31st Imperial Diet as the legislation by members of the Diet was made only to be thrown out and offered every year afterwards, because value of professional accountants had not been socially recognized and business world had not been ready to actively accept them, in addition to negative attitude of regulators (25 years of certified public accountants in Japan, p. 8). Evans talked about the phenomena in Germany that "the annual audit of financial statements remained voluntary in Germany until 1931". On the contrary, Japan did not enter this regime.

2) Evans claims that agency problems and costs arise from the separation of ownership and control in modern companies. It's true that Jensen and Meckling developed their theory on the assumption of the separation of ownership and control in modern companies. They noted, however, that agency costs arise in any situation involving cooperative effort (such as the coauthoring of this paper) by two or more people even though there is no clear-cut principal-agent relationship.

3) AOCHI cited these messages in his writing.

4) In addition to the above, Aochi showed the following episode by prominent businessman at that time SHIBUSAWA EIICHI, who held intimate relations with IWAZAKI Family. According to SHIBUSAWA, Japanese Commercial law helped MITSUBISHI ZAIBATS and others protect their assets and use them with the intention of government to realize the aim of measuring to enrich and strengthen the country [5]. 